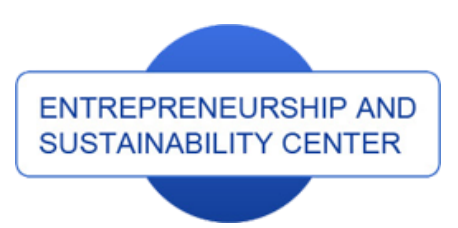

Publisher

http://jssidoi.org/esc/home

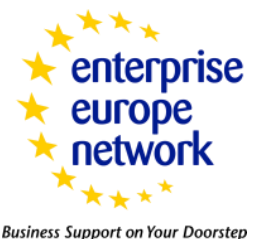

Business Support on Your Doorstep

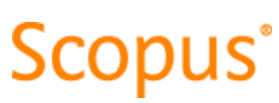

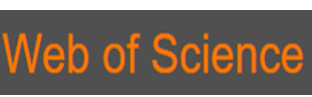

1 Clarivate

Analytics

\title{
ENTREPRENEURSHIP AND INFORMATION TECHNOLOGY BUSINESSES IN ECONOMIC CRISIS
}

\author{
Syed Ali Abbas \\ Turiba University, Zemgale Suburb, LV-1058 Riga, Latvia \\ E-maillali.abbas@uet.edu.pk; aabbas724@gmail.com
}

Received 15 September 2017; accepted 15 January 2018; published 30 March 2018

\begin{abstract}
This paper aims to identify the importance of Information Technology businesses and youth's interest in entrepreneurial initiatives in connection with IT based businesses. The data was collected using questionnaire from final year students of entrepreneurship and computer sciences enrolled in Bachelors, so as to get a profound picture of their intention, motivation and ability to enter in IT related entrepreneurial ventures. As descriptive statistics was used to analyze the findings, the study depicts great motivation among final year graduates to enter in entrepreneurial ventures. They are found to be motivated to establish ventures of their own even at small level. Therefore, SMEs can play vital role in assisting and fostering entrepreneurial activity with special focus on Information Technology businesses. In addition, the research limitation could be the fact that data has been collected from top universities/ institutes in which intellect level of students is competitively high, thus their liking to entre and understanding regarding SMEs and entrepreneurial initiatives is better than students of ordinary institutes. Also, the results could have been deviated if same research was applied in countries with varying demographics. As for practical implementations, the research may be vital for SMEs officials to foresee the entrepreneurial spirit among youth and to design policies accordingly. Also, it opens horizons for information Technology students to consider entrepreneurial careers other than simply applying for jobs in software houses/ organizations. Also, no prior research has been carried out in analyzing the mutual relation of Entrepreneurship and Information Technology businesses, neither the outcome/ joint effect of both has been studied together
\end{abstract}

Keywords: entrepreneurship; information technology; innovation, economic crisis; Global Entrepreneurship Monitor

Reference to this paper should be made as follows: Abbas, S. A. 2018. Entrepreneurship and Information Technology Businesses in Economic Crisis, Entrepreneurship and Sustainability Issues 5(3): 682-692. https://doi.org/10.9770/jesi.2018.5.3(20)

JEL Classifications: A13, A20, D22, L26, M12, M14 


\section{Introduction}

In the era of worsen economic crisis worldwide where financial institution are merging, industries are being downsized, productions are being minimized, as a response to which inflation is rising at a high pace, unemployment is becoming a world's dilemma, money is losing worth, and in total giant economies are collapsing, there still exists a field/sector or an industry which is ever increasing since the time of its existence and even proving out to be a support to falling economies in this time of economic recession, i.e. Information Technology. Look at one of the biggest business growths in the past two decades and names like Facebook, Twitter, Linked In, Free Lancing, etc. are pretty prominent as far as success is concerned. There was a time when chain stores like Wall Mart, Car manufacturers like Benz and Oil producers like Shell used to be a source of inspiration and still they are but in the recent scenario the shift has been magnificently moved towards the I.T giants, mentioned above. The reason for the very fact is the diversification and advancement in the I.T field as these things point out to an immense research topic I.e. "Entrepreneurial Activity in I.T business is a roadmap to success In Economic Crisis", which is the question raised in this research. Chain stores like Wall Mart and brands like Fiat and shell need great investments and involvement of high risks to be established, which in this vulnerable economic recession could be little undesirable to be taken in to consideration by shareholders (especially the mediocre), that's why this tough era needs to be focused on safe play which is possible in the field of Information Technology, as this appears to be one of the solutions of all the modern economic crisis. To support the argument, take an example of an unemployed person who has the opportunity to do free lancing by sitting at home, where his/ her investment could be less as compared to opening a grocery store in which the risk of losing money is high. Surprisingly, in the situation on hand, even if the loss occurs, it won't be devastating as such if the same failure occurs in home based IT startup. Similarly, if two investors want to have a chain of retail outlets, then their investment is secure if they opt to have business like e-bay, rather than opening giant sopping mart which involves high risk and chances of losing money is more than in e bay, as Wall Mart struggled in Germany and had to shut down its operations (Clark, 2006). Same goes with other comparative businesses as well as I.T related business leaves behind the centuries old established brands listed in NYSE/ NASDAQ (Ausick, 2015).

Having said this all, this research paper focuses on analyzing the point, if modern day youth values entrepreneurship, and what is its perception about IT based businesses as a profitable business ventures, especially to counter worsening economic scenarios worldwide.

\section{Literature Review}

"Entrepreneurship is the most powerful economic force to mankind" (Kuratko \& Hodgetts, 2002). Entrepreneurs are individuals who recognize opportunities where others see chaos or confusion. They are aggressive catalysts for change within the market place. They have been compared to Olympic athletes challenges themselves to break new barriers, to long distance runners dealing with the agony of the mile" (Timmons, 1999).

"Entrepreneurship is more than the mere creation of business and the characteristics of seeking opportunities, taking risks beyond security, and having the tenacity to push an idea through reality" (Kuratko \& Hodgetts, 2002).

"Entrepreneurship is the symbol of business tenacity and achievements". The entrepreneur is the aggressive catalyst for change in the world of business. He or she is an independent thinker who dares to be different in a background of common events. The single definition of entrepreneurship doesn't exist considering the openness and depth of entrepreneurship as a concept. Yet, there are some similarities in its literature review which includes personal initiative, the ability to consolidate resources, management skills, a desire for autonomy and risk taking. Other characteristics include competitiveness, goal-oriented behavior, confidence, opportunistic behavior, intuitiveness, reality-based actions, the ability to learn from mistakes and the ability to employ human relations 


\section{The International Journal}

ENTREPRENEURSHIP AND SUSTAINABILITY ISSUES

ISSN 2345-0282 (online) http://jssidoi.org/jesi/

2018 Volume 5 Number 3 (March)

http://doi.org/10.9770/jesi.2018.5.3(20)

skills, ability to undertake cetain risk and make decisions in conditions of uncertainty (Kuratko \& Hodgetts, 2002; Michailova et al., 2017).

As (Rossmiller et al., 2017) describe the failure of conventional SMEs potentially due to lack of usage of technology aided systems rather stressing more on business operations, there must be emphasis on entrepreneurial intellect in the field of technology as well. Also, as per (Johannesson \& Jorgensen, 2017) findings, there is a positive and significant impact of firm's intellectual resources (in terms of professional employees and skilled workers) on entrepreneurial orientation. Moreover, the size and other characteristic features of the start-ups firm is another aspect to be considered (Tvaronavičienè, 2016).

(Cockburn et al., 2000) consider the use of technology in business as one of the changing trends in the era of hyper business and commercialization. In the start of business, entrepreneurs use their technical knowledge as a vibrant resource to overcome resource shortage (Shane, 2008). Reinganum (1983) earlier states that technical innovation and hypothetical suggestion makes difference in competitive innovation. As following innovation is one of the basic characteristics of a successful entrepreneur, it could be beneficial to indulge technology in the ventures.

Shane (2008) relates the technology with three dimensions. These dimensions consist of limited technology, excess of knowledge and intellectual property which entrepreneurs have yet to practice to their full potential. Since entrepreneurs are calculated risk takers, these above mentioned dimensions may affect the risk in business, if executed accordingly. As opportunity and risk go hand in hand, and opportunity is creating or developing goods or services based on uniqueness (Shane, 2012), it's the information technology or in more simple words information-based technology that may guarantee unique products and services, and once the unique product services are developed there is a huge chance of success as compared to when conventional/ traditional product or services are developed.

Talking about historical views on entrepreneurship and economic growth Carree and Thurik (2008) have provided bases for extensive relationship between entrepreneurship and economic growth. This signifies the fact that entrepreneurship affects the economic growth by fostering innovation, creating competition which in turn raises the competitive rivalry. However, it is proven from early literature in 80's that entrepreneurship may play a pivot role in long term economic growth (Lazonick, 1991) which shows that study needs to be moved on from discussing conventional entrepreneurial initiatives to E Commerce and from E-Commerce to M-Commerce which has been stressed in this study. Earlier Wennekers and Thurik (1999) has already constructed an operational framework showing relationship between entrepreneurship and economic growth, therefore need is to focus on the new means as and an ever-increasing demand of entrepreneurial activity.

Bringing economic effects in to discussion empirically, a survey by Storey (1991) validates the unidirectional impact of unemployment on firm start up. Also, the creation of new employment opportunities by starting new ventures has been found by "Schumpeter" effect (Manser \& Picot, 1999). As this study also aims to pinpoint the motivation of students starting own businesses, previous literature by Evans and Leighton (1989) and Reynolds (1999) have already discovered refugee and shopkeeper effect, according to which unemployed individuals prefer self-employment. However, as Van Stel and Storey (1994) talks about refugee push effect in which entrepreneurship may result in self-employment but may not generate any growth, therefore the effort is to find out areas where entrepreneurial growth is highly anticipated and that is the question which is raised in this study.

So, in the light of established theories I.e. neo-classical (Solow, 1956) and endogenous (Romer, 1986) models of economic growth which admit the role of technological innovation in economic growth, the literature is further expanded to discuss Global Entrepreneurship Monitor (GEM). So, continuing secondary research forming strong basis for the study, the table below is comprised of official data from Global Entrepreneurship Monitor which reveals important insights about countries' performance regarding necessary entrepreneurial factors for the respective years. These factors include TEA which accounts for "Total Early Stage Entrepreneurial Activity" and mentions the percentage of entrepreneurs for newly established ventures with their age ranging from 18-64. The 
second factor "Established Business Ownership represents" owner-managers of the established business from which salaries are being paid for more than 42 months. The third factor I.e. "Perceived Opportunities" show the percentage of population who foresee business opportunities in the area they live. The next factor which is named as "Perceived Capabilities" represents the age group from $18-64$ which believe they have the required skills to start new venture. Next in line is "Entrepreneurial Intention" which reflects intention of people to become entrepreneur in next three years. The last of the factors is titled as "Fear of Failure" which indicates the percentage of people whose fear prevents them in establishing a venture. It is also noted here that these factors represent individuals with age range from 18 to 64 (Table 1).

Table 1. Global Entrepreneurship Monitor - Country Profile

\begin{tabular}{|l|l|}
\hline PAKISTAN - Key Indicators 2012 & USA - Key Indicators 2014 \\
\hline TEA: 11.6\% & TEA: 13.8\% \\
Established Business Ownership: 3.8 $\%$ & Established Business Ownership: 6.9\% \\
Perceived Opportunities: 46\% & Perceived Opportunities: 51\% \\
Perceived Capabilities: 49\% & Perceived Capabilities: 53\% \\
Entrepreneurial Intention:25\% & Entrepreneurial Intention: $12 \%$ \\
Fear of Failure: 31\% & Fear of Failure: 30\% \\
\hline LATVIA - Key Indicators 2014 & NIGERIA - Key Indicators 2012 \\
\hline TEA: 13.3\% & TEA: 35\% \\
Established Business Ownership: 8.8\% & Established Business Ownership: $15.7 \%$ \\
Perceived Opportunities: 35\% & Perceived Opportunities: 82\% \\
Perceived Capabilities 23\% & Perceived Capabilities 88\% \\
Entrepreneurial Intention: 23\% & Entrepreneurial Intention: 44\% \\
Fear of Failure: 42\% & Fear of Failure: 21\% \\
\hline INDIA - Key Indicators 2014 & UNITED KINGDOM - Key Indicators \\
\hline TEA: 6.6\% & TEA: 8.6\% \\
Established Business Ownership: 3.7\% & Established Business Ownership: 6\% \\
Perceived Opportunities: 39\% & Perceived Opportunities: 37\% \\
Perceived Capabilities 37\% & Perceived Capabilities 38\% \\
Entrepreneurial Intention: $8 \%$ & Entrepreneurial Intention: $8.5 \%$ \\
Fear of Failure: 38\% & Fear of Failure: 43\% \\
\hline
\end{tabular}

Source: Global Entrepreneurship Monitor, 2016

The table above shows immense variations and make this research an important step in proving a point that Countries though with less GDP comparatively possess vibrant lot of youth and individuals who foresee to establish their ventures depending upon the resources, if provided. Comparing USA with Pakistan, we see the fear of failure factor with 30 and $31 \%$ respectively, is the same but Entrepreneurial Intention is almost double in Pakistan than USA, whereas USA is almost doubled in established business ownership score which is why an entrepreneurial oriented economy is observed in United States. Same goes with promising scores for United Kingdom however, very high fear of failure value is a need to address for UK nationals. India looks pretty low in Entrepreneurial Intention feature which could be due to immense population it carries or it's about people looking for provision of basic facilities in numbers. This point also entails economists to redefine countries' prosperity or economic growth factors other than its GDP scores. Contrastingly, Latvia with low population has mature TEAs value and Entrepreneurial intention is high also but again high FOF value is a case to look at. Taking Nigeria into consideration, all the scores are on higher side with low FOF value indicates that Nigeria being denser in population has understood the importance of entrepreneurial initiatives and on provision of Government assistance it can excel following the Chinese model of economy. Considering other side of the picture, the evaluation of scores lead us also to analyse that countries with high perceived capabilities and having high fear of 
The International Journal

ENTREPRENEURSHIP AND SUSTAINABILITY ISSUES

ISSN 2345-0282 (online) http://jssidoi.org/jesi/

2018 Volume 5 Number 3 (March)

http://doi.org/10.9770/jesi.2018.5.3(20)

failure could be for the fact that people in those countries are already enjoying basic facilities of life with no major differences in income distribution or that they lie somewhere in second or third quadrant of Maslow's Hierarchy of needs that's why going for any business adventure increases their fear for loosing what they already have. Also, there can be many factors that can be linked with the analysis of this table which may include religious element as well as individuals even with little availability of resources take business plunges while leaving the outcome/ future of the initiative on fate. So, as said above this very table can be discussed with many angles. However, as the data has been collected from Pakistan youth, this study could be an important input for GEM authorities for provision of some future statistics for Pakistan, as it lacks the current data

\section{Research Methodology}

It is defined as a highly intellectual human activity used in the investigation of nature and matter and deals specifically with the way data is collected, analysed and interpreted (Holman, 2005)

The objective of this research is to

- Identify the importance of Information Technology businesses among business \& IT graduates

- Analyse the motivation of youth in initiating entrepreneurial ventures

\section{Questionnaire and Sample}

The questionnaire has been tailored while keeping in view data in the Fig 1 below, which is based upon quantitative techniques. A sample of 50 students with proportion of 63.8 male and $36.2 \%$ accounts for female having age group from 20 to 24 years old, was taken using Google forms. The respondents were final year Bachelor students from renowned University of Pakistan from disciplines of computer engineering, computer sciences, marketing and finance. To achieve statistical extractions, descriptive analysis has been used to overview the level of respondents' motivation and capacity to start entrepreneurial ventures in connection with Information Technology based businesses.

\section{Excerpts from the Questionnaire}

As discussed above that the questionnaire was designed to analyse the Information and importance of IT based entrepreneurial ventures, the motivation and the financial capability to start own enterprise, find below few of the questions with likert scale as an excerpt (Table 2).

Table 2. Excerpts from the questionnaire

\begin{tabular}{|c|c|c|c|c|c|}
\hline Information and Importance of IT Based Entrepreneurial Ventures & \multicolumn{5}{|c|}{ Scale - Likert } \\
\hline Information Technology can act as catalyst to economic growth & 1 & 2 & 3 & 4 & 5 \\
\hline Entrepreneurial ideas in the field of IT can assist declining economies & 1 & 2 & 3 & 4 & 5 \\
\hline Motivation to start own Enterprise & \multicolumn{5}{|c|}{ Scale -- Likert } \\
\hline I aim to establish business of my own in future & 1 & 2 & 3 & 4 & 5 \\
\hline I would like to start a business in the field of IT & 1 & 2 & 3 & $\overline{4}$ & 5 \\
\hline \multicolumn{6}{|l|}{ Capability to Start Own Business } \\
\hline I have finances to establish medium size venture & 1 & 2 & 3 & 4 & 5 \\
\hline I can apply for bank loans for investing in mega business projects & 1 & 2 & 3 & 4 & 5 \\
\hline
\end{tabular}




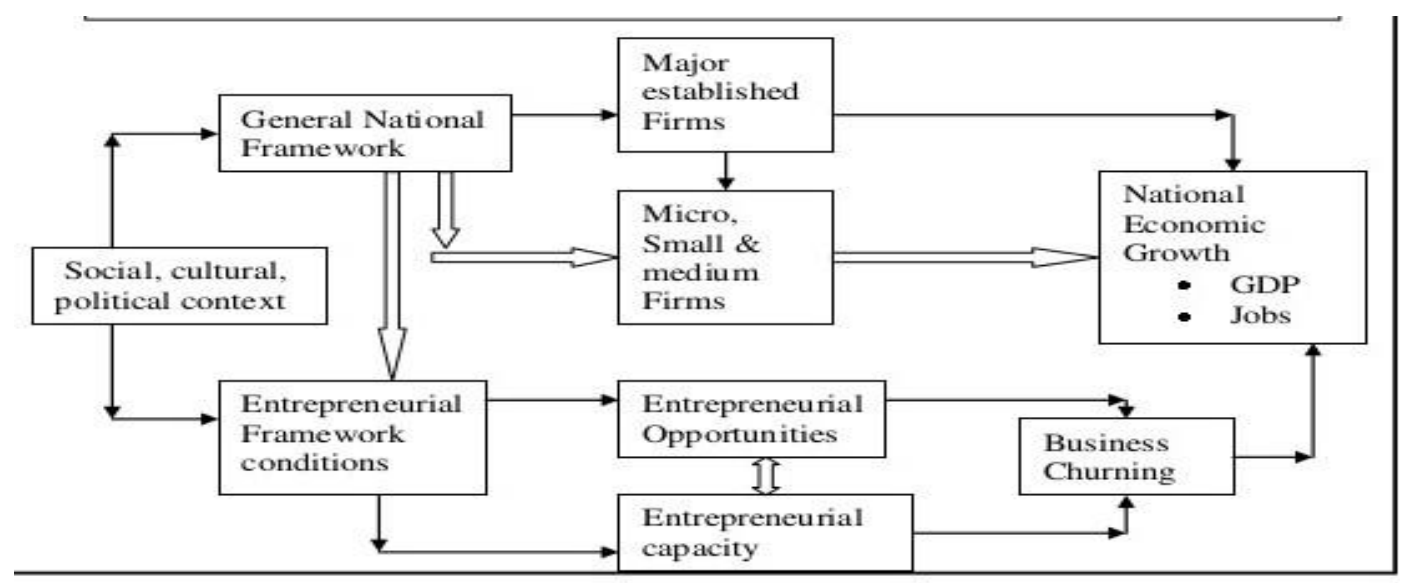

Fig.1 Gem conceptual model of economic growth Source: Global Entrepreneurship Monitor

As Global Entrepreneurship Monitor framework of economic growth has been used as guideline to this study, it signifies the fact that it's social, cultural and political affiliations which effect entrepreneurial initiatives amongst people. These factors lead to exploit entrepreneurial opportunities which with the combination of entrepreneurial capacity lead to business churning. This is the point where this research signifies this model in terms of questions asked from respondents which are divided in following parts I.e. Entrepreneurial motivation \& entrepreneurial capacity and the effect of both on economic growth. The answers from the respondent will not only show the relativity with the model but also give an insight about importance of IT business in edging GDP growth, especially in the context of economies which may show fluctuations.

\section{Findings and Discussions}

Table 3. Cronbach's Alpha Test of Reliability

\begin{tabular}{|r|r|l|}
\hline & $\begin{array}{c}\text { Cronbach's Alpha } \\
\text { Based on } \\
\text { Standardized }\end{array}$ & \\
Cronbach's Alpha & Items & N of Items \\
\hline .738 & .749 & 12 \\
\hline
\end{tabular}

Since the value of Cronbach's alpha is greater than 0.7 (see Table 3), the data and score pass reliability test comprehensively. 
Table. 4 Descriptives for Information and Importance of IT Based Entrepreneurial Ventures - Results

\begin{tabular}{|l|r|r|r|}
\hline & & & \\
& $\begin{array}{c}\text { Entrepreneurship } \\
\text { can foster } \\
\text { economic growth. }\end{array}$ & $\begin{array}{c}\text { Information } \\
\text { Technology } \\
\text { businesses can act } \\
\text { as catalyst to } \\
\text { economic growth. }\end{array}$ & $\begin{array}{c}\text { Entrepreneurial } \\
\text { ideas in the field } \\
\text { of I.T can assist } \\
\text { declining } \\
\text { economies. }\end{array}$ \\
\hline Mean & 1.680 & 1.800 & 2.680 \\
Std. Deviation & .9355 & 1.0102 & 1.2526 \\
Variance & .875 & 1.020 & 1.569 \\
\hline
\end{tabular}

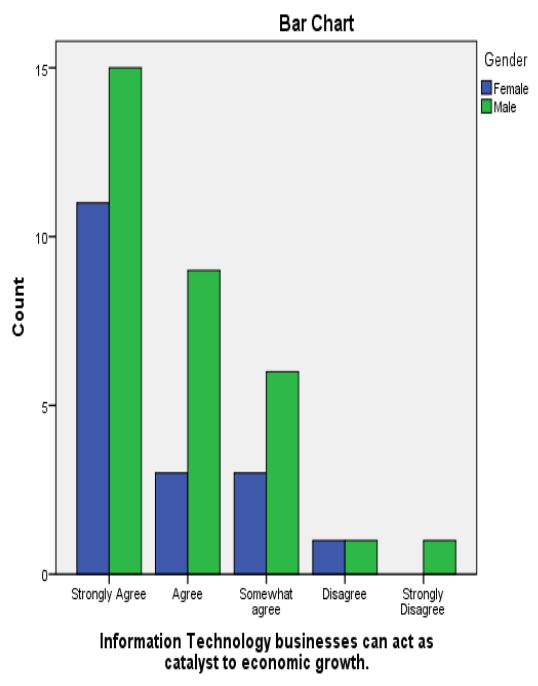

Evident from the results (Table. 4) the above portion of questions is targeted at respondent's view on entrepreneurship and IT and the results show their belief that entrepreneurial ideas, more specifically IT based ventures are a must for economic growth. The key thing to remember here is the gender mix of respondents thus verifying female's interest in entrepreneurial initiatives which could be beneficial for economies in which females have yet to take professional assignments. Their role in IT oriented business may pave a way for them to initiate home based business by just maintaining a perfect balance between family and professional life.

Table. 5 Descriptives for Motivation to start own Enterprise - Results

\begin{tabular}{|c|c|c|c|c|c|c|}
\hline & $\begin{array}{l}\text { Over the years, } \\
\text { I.T based } \\
\text { businesses have } \\
\text { flourished } \\
\text { interestingly }\end{array}$ & $\begin{array}{c}\text { I have } \\
\text { knowledge of } \\
\text { both } \\
\text { entrepreneurship } \\
\text { and I.T. }\end{array}$ & $\begin{array}{c}\text { I aim to } \\
\text { establish a } \\
\text { business of my } \\
\text { own in future. }\end{array}$ & $\begin{array}{c}\text { I would like to } \\
\text { start a business } \\
\text { in the field of } \\
\text { I.T. }\end{array}$ & $\begin{array}{l}\text { I am inspired by } \\
\text { the successful } \\
\text { businesses like } \\
\text { Face book or } \\
\text { Freelancing. }\end{array}$ & $\begin{array}{l}\text { My family or } \\
\text { relatives } \\
\text { comprise of } \\
\text { businessmen } \\
\text { and } \\
\text { entrepreneurs. }\end{array}$ \\
\hline Mean & 1.800 & 1.900 & 2.140 & 2.200 & 2.020 & 2.940 \\
\hline Std. Deviation & 1.0880 & 1.1294 & 1.1954 & 1.2617 & 1.3323 & 1.2521 \\
\hline Variance & 1.184 & 1.276 & 1.429 & 1.592 & 1.775 & 1.568 \\
\hline
\end{tabular}

The above set of questions (Table. 5) shows respondents' motivation for new start-ups. Here it is obvious from the results that not only the respondents are highly motivated to establish their new businesses, despite being in their last semester and are in job hunt process, but they are also inspired by successful business ideas like Facebook or Freelancing. The results of question vowing for their liking for IT related business also meet one of the objectives of the study I.e. "importance of IT related businesses". 
Table 6. Descriptives for Capability to Start Own Business

\begin{tabular}{|l|l|l|l|}
\hline & $\begin{array}{l}\text { I have finances to } \\
\text { establish a } \\
\text { medium size } \\
\text { venture. }\end{array}$ & $\begin{array}{l}\text { I can arrange big } \\
\text { budget to } \\
\text { establish a high } \\
\text { scale business. }\end{array}$ & $\begin{array}{l}\text { I can apply for } \\
\text { bank loans for } \\
\text { investing in mega } \\
\text { business projects. }\end{array}$ \\
\hline Mean & 3.220 & 3.820 & 3.500 \\
Std. Deviation & 1.3445 & 1.3045 & 1.2817 \\
Variance & 1.808 & 1.702 & 1.643 \\
\hline
\end{tabular}

The last few questions (Table 6) depict capacity of respondents whether if they can arrange or possess finance to establish their own setups and unfortunately the results are pretty alarming as highest percentage of respondents lie in the strongly disagree/ disagree column. Along with the shortage of funds the respondent's trust on banking sector in terms of obtaining loans is also on the lower side which is not a good sign, as banks and financial institutions are essential part of positive economic activity but these results; for whatever the reasons, are just not desirable thus opening a room for banking sector to take measures to win people's trust. Considering these findings, previous studies have discussed the impact of Entrepreneurial ventures and their impact on economic growth directly but research on initiation of IT based businesses to foster SME growth is very rare. As (Ezuma \& Ismail, 2017) discuss the role of entrepreneurship and its direct effect on growth, (Coleman \& Robb, 2018) also elaborates the role and effect of women entrepreneurship. So, the results in this study takes entrepreneurial research to next extent as it throws light on the role of IT oriented ventures; while further adding the phenomenon of business and IT graduates as well.

\section{Recommendations and Suggestions}

Based on the results it is therefore recommended that

- Government should foster SME growth to ensure economic development through efficient policy making to edge economies with low Per capita income.

- Entrepreneurship should be made a compulsory subject to be taught in all the disciplines wherever it may fit in e.g. engineering, medical and fine arts etc., if appropriate. This practice is common in European Countries and should be adopted by other countries as well.

- As mandatory in advanced western countries, measures should be taken to foster women entrepreneurship by Government, media and civil society as well.

- Banks should provide entrepreneurial funds/ loan to young pass outs on realistic terms. The need is to formulate the customer oriented and practical terms, so that needful be given opportunities to secure lone also.

- Universities should encourage student entrepreneurial attitude both monetarily and intellectually. Further, creating an enterprise accelerated cell by the universities/ institutes can be a worthy move.

- Information Technology orientation should be enhanced on day to day purchase transactions. As mentioned in results about increasing liking and interest of customers in IT, this move may further track their mind and opinion towards IT oriented businesses. 
The International Journal

ENTREPRENEURSHIP AND SUSTAINABILITY ISSUES

ISSN 2345-0282 (online) http://jssidoi.org/jesi/

2018 Volume 5 Number 3 (March)

http://doi.org/10.9770/jesi.2018.5.3(20)

\section{Conclusion}

This research takes us to conclusion that the current youth has surely got a business mind and possess huge motivation to start its own ventures. A good prospect is that students are not earning degrees only as they consider entrepreneurial ventures an effective tool to increase their earnings. Their motivation is high, and they are also impressed by the recent IT giants thus considering information technology businesses an economic booster that can edge declining economies. This takes us further to conclude that establishing an IT based business based upon computer aided systems and methodologies may not only bring innovation but also guarantees more returns in contrast to less investment which otherwise would have been required in traditional businesses of same level. So, its high time for investors to bring SME sector in perfect alignment with IT based business. Since, banks' aid is important for financing the start-ups, it is mandatory for them to make policies and procedures that allow prospect enterprise to accord with the financing options. In total, it won't be wrong to comment that there is great need to focus on IT based businesses to cope with the worsening economic scenarios, especially when there is great interest and motivation among the youth to start IT based businesses as this is the same youth which is termed as future of any country.

\section{References}

Acs, Z.; Audretsch, D. (eds.). 2010. Handbook of Entrepreneurship Research ISBN 978-1-4419-1191-9 http://www.springer.com/gp/book/9781441911902

Ausick, P. (2015, March 22). 24/7 WALL ST. Retrieved from Facebook Market Cap Tops Verizon and Coke: http://247wallst.com/technology-3/2015/03/22/facebook-market-cap-tops-verizon-and-coke/

Carree, M. A., \& Thurik, A. R. (2008). The Lag Structure of the Impact of Business Ownership on Economic Performance in OECD Countries. Small Business Economics, 30(1), 101-110. https://doi.org/10.1007/s11187-006-9007-0

Clark, A. (2006). Wal-Mart pulls out of Germany. Retrieved from The Guardian: https://www.theguardian.com/business/2006/jul/28/retail.money

Cockburn, I. M., Henderson, R. M. and Stern, S. (2000). Untangling the origins of competitive advantage. Strat. Mgmt. J., 21: 1123-1145. https://doi.org/10.1002/1097-0266(200010/11)21:10/11<1123::AID-SMJ130>3.0.CO;2-R

Coleman, S., \& Robb, A. (2018). Executive forum: linking women's growth-oriented entrepreneurship policy and practice: results from the Rising Tide Angel Training Program. Venture Capital, 20(2), 211-231. https://doi.org/10.1080/13691066.2018.1419845

Country Profile. (2014). Retrieved from Global Entrepreneurship Monitor: http://www.gemconsortium.org/country-profiles

Evans, D. S.; Leighton, L.S. (1989). The Determinants of Changes in U.S. Self-Employment, Small Business Economics 1(2), 111-120

Ezuma, K. E., \& Ismail, M. (2017). Conceptualizing the Influence of Network Competence on Entrepreneurship Growth in Small and Medium Enterprises. Global Business \& Management Research, 9(2), 30-44. https://www.gbmr.ioksp.com/pdf/vol.\%209\%20no.\%202/V9N2-3.pdf

Gumbau Albert, M. (2017). Entrepreneurship, innovation and regional performance: application for the Spanish regions. Entrepreneurship \& Regional Development, 29(3/4), 271-291. https://doi.org/1080/08985626.2016.1267805

Holman, D. (2005). Business Research Methods. Management Learning, 36(2), 266-268. 
The International Journal

ENTREPRENEURSHIP AND SUSTAINABILITY ISSUES

ISSN 2345-0282 (online) http://jssidoi.org/jesi/

2018 Volume 5 Number 3 (March)

http://doi.org/10.9770/jesi.2018.5.3(20)

Johannesson, J., \& Jorgensen, P. (2017). The moderating effect of employee education and professional skills on the relationship between entrepreneurial orientation and performance. Journal of Entrepreneurship Education, 20(2), 1-18. http://dergipark.gov.tr/download/article$\underline{\text { file/367060 }}$

Kuratko \& Hodgetts, (2002). Hodgetts \& Kuratko in conversation VHS video: VHS tape Visual material : View all editions and $\underline{\text { formats }}$

Kuratko, R. $\quad$ M. (2002). Entrepreneurship, Theory; $\quad$ Process \& Practise https://books.google.lt/books?hl=lt\&lr=\&id=6v9UCwAAQBAJ\&oi=fnd\&pg=PR3\&dq=Donald+F.+Kuratko,+R.+M.+(2002).+Entrepreneu rship,+Theory\%3B+Process+\%26+Practise.\&ots=f66ayg4MQ3\&sig=Hy_mm-Lt-

MvTFr6ohXT3q8k_XAc\&redir_esc $=\mathrm{y} \# \mathrm{v}=$ onepage\&q\&f=false

Lazonick, W. (1991). Business Organization and the Myth of the Market Economy, Cambridge, UK: Cambridge

Manser, M. E., \& Picot, G. (1999). The Role of Self-Employment in U.S. and Canadian Job Growth, Monthly Labor Review, 122(4), $10-25$.

https://stats.bls.gov/mlr/1999/04/art2full.pdf

Michailova, J.; Mačiulis, A.; Tvaronavičienè, M.2017. Overconfidence, risk aversion and individual financial decisions in experimental asset markets, Economic research = Ekonomska istraživanja, 30(1), 1119-1131. http://dx.doi.org/10.1080/1331677X.2017.1311234

Reinganum, Marc R. (1983). The Anomalous Stock Market Behavior of Small Firms in January: Empirical Evidence for Tax-Loss Effects, Journal of Financial Economics https://econpapers.repec.org/article/eeejfinec/v 3a12 3ay 3a1983 3ai 3a1 3ap 3a89-104.htm

Reynolds, P. D. (1999). Creative Destruction: Source or Symptom of Economic Growth?' Zoltan J.Acs, Bo Carlsson and Charlie Karlsson (eds.), Entrepreneurship, Small and Medium-sized Enterprises and the Macroeconomy. Cambridge: Cambridge University Press, pp. 97136.

Romer, P. M. (1990). Endogenous Technological Change, Journal of Political Economy 98, S71-S102.

http://pages.stern.nyu.edu/ promer/Endogenous.pdf

Rossmiller, Z., Lawrence, C., Clouse, S., \& Looney, C. (2017). Teaching an Old Dog New Tricks: Disaster Recovery in a Small Business Context. Information Systems Education Journal, 15(2), 13-19. http://isedj.org/2017-15/n2/ISEDJv15n2p13.pdf

Shane, S. (2008). Handbook of Technology and Innovation Management. John Wiley \& Sons, Ltd.

Shane, S. (2012). Reflections on the $2010 \mathrm{amr}$ decade award: delivering on the promise of entrepreneurship as a field of research. Academy Of Management Review, 37(1), 10-20. https://doi.org/10.5465/amr.2011.0078

Solow, R. M. (1956). A Contribution to the Theory of Economic Growth, Quarterly Journal of Economics 70, 65-94.

Storey, D. J. (1991). The Birth of New Firms - Does Unemployment Matter? A Review of the Evidence, Small Business Economics, 3(3), 167-178. https://doi.org/10.1007/BF00400022

Storey, D. J. (1994). Understanding the Small Business Sector, London, UK: Routledge.

Timmons, J. (1999). New Venture Creation (bur Ridge, IL: McGraw-Hill/Irwin) http://www.lem.ep.usp.br/0300021/NewVentureCreationChapter3.pdf

Tvaronavičienè, M. 2016. Start-ups across the EU: if particular tendencies could be trace, Entrepreneurship and Sustainability Issues, 3(3), 290-298. https://doi.org/10.9770/jesi.2016.3.3(6)

Van Stel, A. J., Storey, D. J. (2004). The Link between Firm Births and Job Creation: Is there a Upas Tree Effect?' Regional Studies, 38, 893-909. https://doi.org/10.1080/0034340042000280929

Wennekers, S. \& Thurik, R. (1999). Small Business Economics 13: 27. https://doi.org/10.1023/A:1008063200484 
The International Journal

ENTREPRENEURSHIP AND SUSTAINABILITY ISSUES

ISSN 2345-0282 (online) http://jssidoi.org/jesi/

2018 Volume 5 Number 3 (March)

http://doi.org/10.9770/jesi.2018.5.3(20)

Syed Ali ABBAS is a PhD (A.B.D) at Turiba University Riga and holds master's degree in Business Management \& Entrepreneurship from SAMK, Finland with another MBA degree from UVAS, Lahore. Currently on Pedagogy assignment at Poznan University of Economics Poland under Erasmus Mobility, Ali has previously served as lecturer in University of Economics and Management, Prague under the same mobility programm. He has also served as Lecturer at IB\&M University of Engeneering and Technology Lahore and been an attende of research methodology course at BI Norweigian Business School as well. Research interests: entrepreneurship and SME growth; Higher Education Branding; Leadership.

ORCID ID: http://orcid.org/0000-0002-3634-6615

Register for an ORCID ID:

https://orcid.org/register

Copyright (C) 2018 by author(s) and VsI Entrepreneurship and Sustainability Center

This work is licensed under the Creative Commons Attribution International License (CC BY).

http://creativecommons.org/licenses/by/4.0/

c) (7) Open Access 